INDEPENDENT JOURNAL OF MANAGEMENT \& PRODUCTION (IJM\&P)

http://www.ijmp.jor.br

v. 12, n. 6, Special Edition ISE, S\&P - November 2021

ISSN: 2236-269X

DOI: 10.14807/ijmp.v12i6.1754

\title{
MANAGEMENT OF TEACHER EDUCATION: DANISH DEMOCRATIC DISCOURSE IN POSTMODERN ERA
}

Anhelina Roliak

State Agrarian and Engineering University in Podilya, Ukraine E-mail: rolyakangel@gmail.com

Olena Matiienko Vinnytsia Mykhailo Kotsiubynskyi State Pedagogical University, Ukraine

E-mail:e_matienko@ukr.net

Elvira Manzhos

National Pirogov Memorial Medical University, Ukraine E-mail:elviramanzhos@gmail.com

Olena Shamanska Vinnytsia Mykhailo Kotsiubynskyi State Pedagogical University, Ukraine E-mail: Shamanska.lena@gmail.com

Nelya Burlaka Mykhailo Kotsiubynskyi State Pedagogical University, Ukraine E-mail: burlaka_10@i.ua

Submission: 8/7/2021 Revision: 9/13/2021 Accept: 9/26/2021

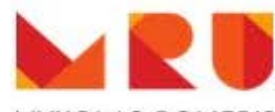

MYKOLAS ROMERIS UNIVERSITY

\section{ABSTRACT}

In postmodern area, flexible and innovative management should become an integral part of the European education system as every knowledge-based society demands to educate high-quality specialists. The present research combines two dimensions: structural and administrative, including a dual fringe of both management and teacher education environments in the Nordic democratic space. The article offers a comparative analysis of the structural model, administrative principles, and new management initiatives in teacher professional training within the tertiary education system of neo-liberal Denmark. The Danish context is the most essential because this country has gained a unique experience in creating an effective system of self-governing teacher education institutions existing on a relevant background of centralized and decentralized management principles. 
DOI: 10.14807/ijmp.v12i6.1754

The methodological contribution of this research is based on a case study approach that includes methods of qualitative analysis, critical induction, information reinterpretation, and generalization. Neo-liberal management initiatives of the Danish democratic state aimed at improving pedagogical education after postmodern period are considered to be a part of the response to the ongoing need for high-quality professional training of teachers based on a solid foundation of autonomy and effective innovative practices.

Keywords: pedagogical education; Danish discourse; management principles; centralization; decentralization; self-government

\section{INTRODUCTION}

The age of postmodernity initiated profound transformation in educational systems of the knowledge-based societies. Postmodern education becomes more diverse, consumerist, fragmented, domain-specific and media-saturated and allows individuals much more freedom of choice. In these circumstances teachers are expected to be highly competent professionals, able to decide multitask problems in pedagogical issues, curriculum, leadership, etc. Such an exploration invokes new questions in turn for pedagogic education itself and its compliance with today's social needs and labor market. That is why it is so important to find out updated management approaches that will lead to improvement and progress of teacher education system from the point of view of the global world, European and national context.

Our comparative investigation shows that in European countries, and particularly in Denmark contemporary management of teacher education has been evolving as a system of administrative regulations based on democratic and self-governing principles. The conceptual idea of our research is based on the realization of the fact that in Danish teacher professional training the existing organization of educational management is an important branch of the national regulatory system. It is a social and economic phenomenon considered to be the dynamic and flexible integrity, based on neo-liberal, democratic principles and concepts of institutional autonomy, equality, community participation, and support of collegiality and collaboration in decision-making. Effective management inevitably combines both specific internal national traditions of a separate country and also different external tendencies such as globalization, internationalization, creation of a European and world educational environment, etc.

That is why, for the most detailed understanding of the democratic principles in the management system of teacher education, and formation of the efficient educational 
DOI: 10.14807/ijmp.v12i6.1754

management model, it is necessary to analyze the interdependence in global and national similar features and to classify them into one general scheme, acceptable in the Ukrainian state.

\subsection{Research aims and tasks}

The subject matter of our study is the organization of general management and administration of tertiary teacher education in postmodern Danish environment. The following goals will be considered more distinctively: 1) to conceptualize theoretical background of educational management; 2) to examine the structural peculiarities of teacher education in Denmark; 3) to define and characterize the basic management principles of teacher education through postmodern democratic process, and; 4) to analyze new management initiatives aimed at improving pedagogic tertiary education in Danish environment.

\section{LITERATURE REVIEW}

To clarify the pathways of pedagogic education management from different perspectives we start our study with a review of the European and Ukrainian scholars' research literature. Definitions of strategic management directed on the development and modernization of the teacher education systems are of concern to the entire world community today.

Recently there were appeared new studies of Ukrainian scientists, connected with modern changes in the quality of education as a whole and the analysis of foreign experience in teacher professional training administration and control. The general trends in the development of humanistic pedagogic education in democratic states were highlighted by such Ukrainian comparativists as Mukan and Kravets (2016), Lytovchenko, and Ogienko (2010). The management principles of the organization of teacher training in higher education institutions of European countries were revealed by Pukhovska, Tezikova, Bazeliuk and Muzichenko (2010), Leshchenko, and others (2014).

Our comparative study of the modern European environment confirms that the number of studies on the subject of effective democratic educational management has increased significantly. The research demonstrates that Bush (2011), Engeström, and Sannino, (2011) investigate educational management as an applied field of public administration and reveal its contradictions with the postmodern organizational transformation of teacher education. Swedish scientist Lundahl (2016) depicts management of the Nordic model of teacher education on behalf of equality, inclusion, and marketization. European experts Nusche, Radinger, Falch, and Shawn (2016) analyze the necessity of changes in educational management principles with the postmodern reforms in neoliberal Danish environment. 
DOI: 10.14807/ijmp.v12i6.1754

Although comparative research in educational management is growing, investigations into the subject of proportional analysis with an emphasis on the pedagogical education dimension are infrequent, except a few examples (Roliak, 2020). Nevertheless, the content analysis of the received data from pedagogical literature and dissertations has demonstrated that the problem of effective administration and governing of tertiary institutions in the teacher training systems in Danish and Ukrainian environments, was not the issue of a systematic study. So that is why we think this aspect requires a special inquiry.

\section{DATA AND METHODOLOGY}

\subsection{Methodology of Qualitative Analysis}

The methodological contribution of this research is based on a case study approach that includes methods of qualitative analysis, critical induction, information reinterpretation and generalization (Hodge \& Sharp 2016).

Critical collaborative investigation along with contextualized comparison have been carried out to identify structural characteristics and management peculiarities of teacher tertiary education in Denmark of postmodern area (Stake, 2005).

A key point in this collaborative investigation is the method of arranging the meaning, when participants can understand, examine and transform the research results. In this perspective, joint teamwork of researchers and participants develop the process of authentic expertise (Engeström, Miettinen \& Pünamäki, 2003).

\subsection{Research Design and Participants}

Multiple sources of Ukrainian, European, and Danish educational environments at various time points from 1997 to 2021 were used as the basic information for this study. Three social and cultural generations of scientific projects that researched the topic were systematized: materials and theses of scientific conferences conducted by national and international scientific organizations discussing the problems of teacher education management, Eurydice reports on lifelong education in Europe; documents of European Association for Teacher Education (EATA); European pedagogical periodicals, in particular: Special Issue in European Journal of Education, European Educational Research Journal, Scandinavian Journal of Educational Research, Pædagogik, Danish Statistical Yearbook.

Three systematic essential steps were conducted in searching and transforming the received information. The first introductory stage included compellation of existing research 
DOI: 10.14807/ijmp.v12i6.1754

data (in the Internet base) according to the object of the study. On the second selective stage the data were chosen for its inclusion into the current study within the publication context, time limits, languages (English, Ukrainian and Danish). The third stage of synthesis was arranged through both distance and live-discussions of the research results and critical feedback from Danish and Ukrainian scholars.

To bring separate isolated data into interconnection with each other and to build simple relations between teacher education and management into a complex system, we apply a broad scheme of scientific debates with the Danish scholars through Internet resources distantly, in a short-term research project within the funds of the Royal Library of Denmark in Copenhagen, and during the authors' personal participation in European ECER Conferences, seminars and round tables, arranged in Denmark and Nordic countries. Thus this article could be seen as a summative work of different comparative research projects focusing on the questions of management and administration in Danish teacher education system.

\section{RESULTS}

\subsection{Educational management definitions}

Focusing on the analysis of the accepted definitions of the term "educational management” we cannot but mention that historically its theoretical principles were derived from the classical organization theories of Fayol (1949), Weber (1947), and Taylor (1947), founders of industrial, democratic and scientific management. These scholars contributed significantly to the development of classical educational management theory.

Compiling Taylor's scientific management concepts, with Weber's democratic approach, and Fayol's administrative theory of the organization, Heck and Hallinger (2005) connect the term educational management with modern changes in school education and leadership.

Whereas Bush (2011), applies the term to the whole system of education. He states, that educational management is concerned with the functioning and organization of institutions that provide teaching and learning at all levels.

Although differences of opinions among scholars still exist, there appears to be some agreement that educational management has three-dimensional subspaces that refer to the following:

a) techniques to organize school work (often called as school leadership), 
DOI: 10.14807/ijmp.v12i6.1754

b) tools of any educational institution control;

c) general provision of administration and supremacy in the country's education system (Roliak et al., 2020).

We must stress that the first two dimensions are not included as the subject of our research.

Taking into account the third dimension of wide-ranging governance of the educational system as a whole, we assume that, due to its origin, educational management is used to fulfill the following functions: planning, organization, directing, coordination, and evaluation the progress in the system's components (Bush, 2011).

For a detailed study of the pedagogic education management model in Denmark, let us dwell on general structural peculiarities characteristics of this country's teachers' training system. Bearing in mind Bush (2011) management models, the Danish teacher training system should be described as a flexible one with the effective combination of centralization and decentralization processes as well as autonomy and individual control in different spheres of pedagogic education.

\subsection{Structural features of teacher education in Denmark}

Our research reveals that in the field of teacher professional training, Denmark goes its own way and has its own management strategies. In the new millennium we distinguish two peculiar features of Danish teacher education: 1) Denmark is the only Nordic country that has a dual system of tertiary pedagogic education; 2) this country has well-built coordination of a broad non-formal component with formal constituents (Roliak, 2020).

To better understand the mechanisms of educational management in the Danish pedagogic environment we should explain exactly the notion of “duality”, which has extensive historical roots. Numerous studies have observed that tertiary education of teachers for Danish schools has two dimensions (Table 1): 1) college-based (or as they call it in Nordic countries seminarium-based), and 2) university-based. Despite the fact, that seminarium education, being for more than two hundred years the foundation for teacher training in the Nordic countries, seems no longer be an adequate basis in the postmodern knowledge societies, most European countries moved exclusively to the academic model in training of school teachers. Denmark has withstood pressure from all the Nordic countries and most of the European Union and retain two types of tertiary educational institutions (Rasmussen, 2008). 
INDEPENDENT JOURNAL OF MANAGEMENT \& PRODUCTION (IJM\&P)

http://www.ijmp.jor.br

v. 12, n. 6, Special Edition ISE, S\&P - November 2021

ISSN: 2236-269X

DOI: 10.14807/ijmp.v12i6.1754

Table 1: Duality of Teacher Tertiary Education in Denmark

\begin{tabular}{|c|c|c|}
\hline \multicolumn{2}{|c|}{ Formal teacher education } & Non-formal component \\
\hline University Colleges & Universities & Universities+Colleges+Unions \\
\hline $\begin{array}{c}\text { Professional Bachelor (KVU) - 1,5- } \\
2 \text { years }\end{array}$ & $\begin{array}{c}\text { Bachelor of Education } \\
\text { (MVU) }\end{array}$ & Higher Preparatory Exam (HF) \\
\cline { 3 - 3 } $\begin{array}{c}\text { Bachelor (MVU) - } \\
4 \text { years }\end{array}$ & Pedagogic practial training \\
\cline { 2 - 3 } & $\begin{array}{c}\text { Master of Education } \\
\text { (LVU) } \\
4+1 / 1,5 \text { years }\end{array}$ & Extension Service \\
\hline
\end{tabular}

Source: compiled by the authors, based on (Roliak, Matiienko, Koliadych, Yatsyshin, \& Dakaliuk, 2020.

So consequently, as it is demonstrated on the Table 1 , the duality of teacher training system in Denmark of postmodern period can be described as the following.

On one hand, Danish university colleges (former seminariums) provide medium-term (MVU - mellemfristet videregående uddannelse) Bachelor of Education programs. University colleges (University College of South Denmark, University College Absalon, University College Copenhagen) are unique Danish non-profit institutions under public administration. They offer four years of specialized pedagogical training for future teachers of folk schools. On the other hand, Danish universities (University of Copenhagen, Aalborg University, Odense University, etc) propose long-term (LVU - langsigtet videregående uddannelse) Master of Education programs for teachers of upper secondary schools (Roliak, 2020).

Our study indicates that as the result of current structural transformations, short-term (kortvarig videregående uddannelse - KVU) programs recently became available in Danish teacher education (Eurydice, 2019). European data demonstrate that postmodern Denmark suffers from an insufficient number of teaching staff for secondary schools. Thus in 2015, the number of admissions to Danish pedagogical higher education institutions was 2,943 students, compared with 3,710 applicants in 2011 (Kof, 2017).

So the Danish Ministry of Education submitted a flexible innovative management program for mobile training of teachers, starting the experiment between the University College of Northern Denmark and the University of Aalborg, including the non-formal branch of Higher Preparatory Exams (HF), offered at adult education centres (VUC Centres). Subsequently, an alternative pathway to obtaining teacher qualification makes it possible for students to begin a study program without having to decide whether to become a teacher in primary, lower, or upper secondary school.

Moreover, this integrated program allows students with prior vocational work experience or a higher education degree to transfer credits from relevant (vocational) practice 
DOI: 10.14807/ijmp.v12i6.1754

to teacher education. Hence, the program is comparatively short and lasts only for two and a half years, comprising 150 ECTS. Therefore more teachers in a shorter period may join pedagogic teams satisfying labor market needs as well as the interests of every particular Danish school (Roliak, 2020).

The abovementioned facts raise the possibility of emphasizing that in the period of postmodern reforms, Denmark continues to build its teacher education as a comprehensive, consistent and progressive system. It is mainly based on guiding principles: democracy, flexibility, accessibility, and strong connection with the needs of the Danish society. This information shows a need for a unique management system, which we examine further in our study.

\subsection{Management of teacher education: Danish democratic environment}

In this section, the current situation in the management of tertiary teacher education in Danish discourse is considered broadly in relation to the duality in structure and democracy in national policy. We have investigated, that Denmark is a country, that has created a democratic and efficient teacher education system in Europe, due to the successful combination of centralization and decentralization management principles, with the objective to achieve mission and vision of national education strategy, taking into account public opinion on the improvement of this branch of the education system (Act).

Relying on the Danish experience, the centralized management of the pedagogical education provides an implementation of the general regulation and creation of conditions for strategic objectives realization through two branches: the Ministry of Higher Education and Science, and to a lesser extent, the Ministry of Education.

Thus, these two Ministries define only the main guidelines of both tertiary teacher education as well as pedagogical in-service training and provide overall recommendations regarding the admission of students, the structure of studies, awarding of degrees and appointment of teachers and academic staff, priority in educational goals of all offered programs.

Decentralized management of the Danish pedagogical tertiary education is highlighted in the "University Act", and "Consolidation Act on University Colleges for Higher Education", stating that control over the educational activity is related to the functions of local authorities. Therefore, the municipal authorities through the self-governing Councils of higher educational institutions with several representatives of regional administrative structures, ensure 
DOI: 10.14807/ijmp.v12i6.1754

coordination of teacher education at the regional level (LBK nr 261 af 18/03/2015; LBK nr 779 af 08/08/2019).

According to the abovementioned Acts, Danish teacher training colleges and universities are government-funded independent institutions within the public administration. The organization of both universities and colleges is based on a vertical management structure with a board as the supreme authority of both types of institutions. Universities' and colleges' boards have the general and strategic responsibility for the quality and development of education at the institutions.

The management of the institution also includes the responsibility for educational activities, efficiency and economy. Though, if we speak about educational activities, we must bring into focus the differences of the long-term educational aims of colleges on one hand, and universities on the other. The universities' pedagogic education is research-based, while colleges' teacher training is practice-oriented. Proceeding from these facts we assume, that there must be some distinctions in the educational approaches, technologies, program context, etc.

So, identifying features of decentralized management, both types of institutions of tertiary pedagogic education in Denmark continue to provide a long tradition of academic freedom, autonomy, and self-governance. The teacher training institutions have the sovereign responsibility for drawing up and updating their study programs, indicating the aims, scope, and duration, form, and contents of the courses as well as a description of the syllabus.

In such a way, ensuring educational opportunities for all to acquire high-quality pedagogic education and development (Blossing \& Moos, 2014). From a democratic perspective, according to Danish law, the task of educational institutions is not only to ensure the guarantees of every citizen for education but also to create conditions for self-determination and self-realization of an individual (LBK nr 779).

\section{DISCUSSION}

\subsection{New management initiatives: postmodern era}

The recent comparative study of teacher education in Nordic countries indicates that young people in Denmark perceive teacher education as having a low level of prestige (OECD, 2020). The evidence-based reports of Danish educational reforms, explored central problems, such as the low prestige of the teaching profession, declining student numbers, and a high 
DOI: 10.14807/ijmp.v12i6.1754

dropout rate of students entering initial teachers training programs (as much as $41 \%$ according to the data from statistics of Denmark) (European Comission, 2013; OECD, 2016).

Neo-liberal management initiatives to improve pedagogical education in postmodern Denmark are considered to be the part of the response to this ongoing need for high-quality initial and continuing professional development of teachers. As teacher education hinges on three stages: during initial teacher education (ITE), at the induction stage (for early-career teachers), and throughout the teaching career (CPD), it is important to focus on management measures according to each of the stage.

- Management measures to improve initial teacher education. In 2018, the Danish Parliament passed an act on a new National Institution for guidance on higher education and careers (Studievalg Danmark). This institution aims to assist young people in upper secondary schools in their choice toward a higher education program (including pedagogical one). So today seven regional guidance centers in Denmark are responsible for academic guidance in each of their respective regions (OECD, 2016).

- Regionalization of tertiary pedagogic education. Nowadays, the Danish government wants to build a more balanced educational management by establishing the so-called "educational stations" as higher education local units. The idea is that all educational stations are located in areas with high labor demand for teachers but limited or even non-existent tertiary education programs. Monitoring this situation, a station offers and promotes a higher education program of the nearest college or university. In total, the government has allocated 160 million DKK for these stations' establishment. It is estimated that by 2021 the ten new stations will host 500-1000 students, including future teachers, for Danish tertiary education (EURYDICE, 2019).

- Regulation changes for admission to higher pedagogical education. Due to the COVID19 situation, the number of applicants to teacher education institutions in Denmark was expected to rise significantly to 500 extra students. The management initiative of the Danish government and all parties in the parliament is to allocate funds allowing pedagogical education institutions to create extra student places in 2020 and 2021. The other significant regulation change in the teacher training program is that the required grade point average for admission has decreased, resulting in a record number of student teachers who were offered a place in tertiary pedagogic education in July 2020 (EURYDICE, 2020). 
- Measures to improve early career support. The analysis of available information and data shows that in 2012 the Eurydice report differentiated the induction period of a teacher as the starting point in a professional qualification of a pedagogue. As the result of the initiative of Danish local councils, the programs "for developing coherent and system-wide induction for beginning teachers” were launched among the country's Folk schools. According to this program, every first-year teacher enters the career with a mentor who provides early career support, helping the beginning teachers in the decision-making processes.

Such initiatives meet the expectations of the Danish top educational administration to increase the number of high-quality teachers and to implement a coherent and sustainable (internal and external) management strategy for improving the image and the prestige of the teaching profession.

\section{CONCLUSIONS AND RECOMMENDATIONS}

The current study found that though terms "educational management" and "management of education" have similar translation in different languages (German, French, Ukrainian, Russian, Spanish, etc), their content is not always the same.

The most interesting finding is that the term "educational management” is used in much wider meaning than "management of education”. Bearing this in mind our research reveals management in the field of Danish teacher professional training as regulatory instrument of administrative initiatives. In return we conclude that Denmark goes its peculiar way and has its own neo democratic management strategies supporting the idea of construction of the safe and attractive education environment based on mutual respect, cooperation and freedom of choice.

The conducted comparative analysis of the structural model, administrative principles, and new management initiatives in teacher professional training within the tertiary education system of neo-liberal Denmark showed that this country managed to keep the dual system of teachers training, i.e. the coexistence of two types of higher education institutions offering teacher training programs - university colleges of education and universities.

Moreover, this duality in structure emerged as a reliable predictor of the duality in management which is manifested at the level of the municipal Councils, with separate administrative departments for colleges and universities exactly. Whereas flexible and innovative management, built on centralized and decentralized principles have become an integral part of the teacher education system in postmodern knowledge-based Denmark. 
Returning to the question of new management initiatives posed at the beginning of this study, it is now possible to state, that they include the following regulatory measures aimed at:

a) improving initial teacher education;

b) regionalization of tertiary pedagogic education;

c) regulating admission to higher pedagogical education;

d) providing early career support.

Our investigation proves that postmodern Denmark is constructing a highly efficient management of teacher education system where its structure, and democratic principles correspond to the major goals - to fulfill the society's demands to educate high-quality pedagogic specialists, and to give the right for everybody in the knowledge-based society to acquire competences to meet the needs of the contemporary labor market.

We consider that this research subject is far-reaching. The necessity of continuous study is determined by the importance of the discussed problems.

We see the prospects for further comparative investigation in the following:

a) techniques to organize pedagogical work (often called as leadership),

b) tools of any educational institution self-government and control;

c) management principles of dual career development environment;

d) general provision of colleges and universities administration both in Nordic and Ukrainian dimensions.

\section{CONFLICT OF INTERESTS}

The author states that there is no conflict of interest.

\section{REFERENCES}

Agerskov, U. (Ed.). (2012). Statistical Yearbook 2012. Copenhagen: Statistics Denmark. Blossing, U., Imsen, G., \& Moos, L. (Eds.). (2014). The Nordic Education Model. 'A

School for All' Encounters Neo-Liberal Policy. Dordrecht: Springer.

Bush, T. (2011). Theories of Educational Leadership \& Management. $4^{\text {th }}$ edition. SAGE Publications LTD.

Dewey, J. [1916] (1995). Democracy and Education: An Introduction to the Philosophy of Education. New York: Macmillan. 
Engeström, Y., \& Sannino, A. (2011). Discursive manifestations of contradictions in organizational change efforts. A methodological framework. Journal of Organizational Change Management, 24(3), 368-387.

Engeström, Y., Miettinen, R., \& Pünamäki, R-L. (eds.). (2003). Perspectives on Activity Theory. Cambridge: Cambridge Universitary Press.

EUROPEAN COMISSION (2013). Study on Policy Measures to improve the Attractiveness of the Teaching Profession in Europe: Final report. Volume 1. Luxembourg: Publications Office of the European Union.

EURYDICE (2019) Structural Indicators for Monitoring Education and Training Systems in Europe - 2019: Overview of major reforms since 2015. Eurydice Report. Luxembourg: Publications Office of the European Union.

EURYDICE (2020). Denmark. National Reforms in Higher Education. Available: https://eacea.ec.europa.eu/national-policies/eurydice/content/national-reforms-highereducation-18_en.

Fayol, H. (1949). General and industrial management. London: Pitman.

Heck, R., H., \& Hallinger, P. (2005). The Study of Educational Leadership and Management. Where Does the Field Stand Today? Educational Management Administration Leadership, 33(2), 229-244.

Humeniuk, I., Kuntso, O., Popel, N., \& Voloshchuk, Y. (2021). Mastering listening comprehension at ESP classes using TED TALKS. Advanced Education, 17(8), 27-34. DOI: https://doi.org/10.20535/2410-8286.226733.

KOF (2017). The KOF Education System Factbook: Denmark. 1st ed. Zurich: KOF Swiss Economic Institute.

LBK nr 261 af 18/03/2015. Bekendtgørelse af lov om universiteter (universitetsloven) [The University Act]. Available: https://www.retsinformation.dk/eli/lta/2015/261.

LBK nr 779 af 08/08/2019. Bekendtgørelse af lov om professionshøjskoler for videregående uddannelser [Consolidation act on University Colleges for Higher Education]. Available: https://www.retsinformation.dk/eli/lta/2019/779.

Leshchenko, M., \& Yatsishin, A. (2014). Category of “Open Education” in the Work of Native and Foreign Scientists. Information Technologies and Learning Tools, 1(39), 1-16.

Mukan, N., Myskiv, I., \& Kravets, S. (2016). The Characteristics of the Systems of Continuing Pedagogical Education in Great Britain, Canada and the USA. Comparative Professional Pedagogy, 2(6), 20-25.

Nusche, D. et al. (2016). OECD Reviews of School Resources: Denmark 2016, OECD Reviews of School Resources. Paris: OECD Publishing. DOI: http://dx.doi.org/10.1787/9789264262430-en.

OECD (2016). OECD Reviews of School Resources: Denmark 2016. Paris: OECD Publishing.

OECD (2020). TALIS 2018 Results: Teachers and School Leaders as Valued Professionals. Volume II. Paris: TALIS, OECD Publishing.

Ogienko, O., \& Lytovchenko, I. (2010). Tendencies of higher professional education development in the information society: Ukrainian context. Edukacja -Technika Informatyka, 1(2), 97-102. 
INDEPENDENT JOURNAL OF MANAGEMENT \& PRODUCTION (IJM\&P)

http://www.ijmp.jor.br

v. 12, n. 6, Special Edition ISE, S\&P - November 2021

ISSN: 2236-269X

DOI: 10.14807/ijmp.v12i6.1754

Ogienko, O., \& Rolyak, A. (2009). Competent Approach in Teachers Professional Training in Context of Integration to the European Educational Environment. Paper presented at International European Conference on Educational Research (ECER): Theory and Evidence in European Educational Research, September 25-27, Vienna, Austria.

Parasii-Verhunenko, I., Kuznetsova, I., Misko, H., Biriuk, O. \& Zharikova, O. (2020). Strategic Analysis of the Competitiveness of Educational Products in the Management of Higher Education Institutions. Independent Journal of Management \& Production, 11(9), 2496-2515. DOI: http://dx.doi.org/10.14807/ijmp.v11i9.1421.

Pukhovska, L., Tezikova, S., Bazeliuk, N., \& Muzichenko, Yu. (2010). Constructing the training process model for the European dimension implementation into the in-service teacher training in Ukraine. Paper presented at the European Conference on Educational Research (ECER): Education and Cultural Change, August 23-27. Helsinki, Finland.

Rasmussen, J. (2008). Nordic Teacher Education Programmes in a Period of Transition: The End of the Well-established and Long Tradition of 'Seminarium'-based Education? In: Brian Hudson and Pavel Zgaga (eds.).Teacher education Policy in Europe: a Voice of Higher Education Institutions. Umea: University of Umea, 325-345.

Roliak, A. (2020). Professional education of teachers in physical training and health: the experience of Denmark. Pedagogy of Physical Culture and Sports, 24(3), 143-150. DOI: https://doi.org/10.15561/26649837.2020.0307.

Roliak, A., Dutka, H., Mylytsya, K., Matiienko, O., \& Oliinyk, N. (2021). Problem-based Learning in Pedagogic Tertiary Education: European Context Through Denmark Environment. Independent Journal of Management \& Production, 2(3), s071-s084. DOI: https://doi.org/10.14807/ijmp.v12i3.1521.

Roliak, A., Matiienko, O., Koliadych, Yu., Yatsyshin, O., \& Dakaliuk, O. (2020). Adults as Non-traditional Students in the Tertiary Education of Denmark and Ukraine: Comparative Discourse of Structural, Psychologic and Pedagogic Peculiarities. Independent Journal of Management \& Production, 11(9), 2215-2234. DOI:

http://dx.doi.org/10.14807/ijmp.v11i9.1411.

Stake, R. (2005). Qualitative case studies. In N. K. Denzin, Y. S. Lincoln. The SAGE handbook of qualitative research, Sage: Thousand Oaks, CA. 443-466.

Staugaard, H. J., \& Rasmussen, P. (2010). Current challenges to teacher education in Denmark. Paper presented at the 11th Nordic Conference on Teacher Education, May 78. Hjørring, Denmark.

Taylor, F. W., \& Person, H. S. (1947). Scientific management. New York: Harper.

UNDERVISNINGSMINISTERIET (2008). Bekendtgørelse om ændring af bekendtgørelse om uddannelsen til professionsbachelor som lærer i folkeskolen № 441, 02-06-2008.

Available: https: //www.retsinformation.dk/Forms/R0710.aspx?id=117184.

Weber, M., Henderson, A. M., \& Parsons, T. (1947). The theory of social and economic organization. Mansfield Centre, CT: Martino Publishing. 